\title{
STRUCTURAL FACTORS FOR A THIRD-GENERATION PORT: CURRENT STATE, LIMITS AND WEAKNESSES OF GIOIA TAURO, ITALY, IN THE REGIONAL TRANSPORT PLAN
}

\author{
FRANCESCO RUSSO ${ }^{1} \&$ GIOVANNA CHILÀ ${ }^{2}$ \\ ${ }^{1}$ Dipartimento di Ingegneria dell'Informazione, delle Infrastrutture e dell'Energia Sostenibile, \\ Università Mediterranea di Reggio Calabria, Italy \\ ${ }^{2}$ Environment and Public Works, Municipality of Motta San Giovanni, Italy
}

\begin{abstract}
Third-generation ports emerged in the 1980s, principally due to world-wide large-scale containerisation combined with the growing requirements of the international trade. The ports have been turning into integrated transport centres and logistic platforms for international trade; activities and services are specialised and integrated. The aim of this paper is to present the methodology to identify structural factors for the realisation of a Gioia Tauro third-generation port, starting from the analysis and the goals of Calabria Regional Transport Plan (RTP). The current state, limits and weakness of Gioia Tauro's port are highlighted. The Calabria's RTP on the one hand becomes the connection tool between institutional policies of various territorial levels, on the other it becomes an important element for the development of specific actions. Further work analyses the action and the measures that operate to reduce the limits and the weakness exalting the potentiality.
\end{abstract}

Keywords: regional transport plan, third-generation port, planning, maritime network, logistics systems.

\section{INTRODUCTION}

Third-generation ports [1] emerged in the 1980s, principally due to world-wide large-scale containerisation and intermodal transport combined with the growing requirements of the international trade. The ports have been turning into integrated transport centres and logistic platforms for international trade. Activities and services in such third-generation ports are specialized, variable and integrated.

The aim of this paper is to analyse actually condition to Gioia Tauro port, in the context of port system of Calabria Region. Calabria is an Italian region, located in the southern part of the Italian state, in the centre of the Mediterranean.

The port of Gioia Tauro was designed in the 1960s as an industrial port, serving the 5 th Italian Steel Centre. Construction work began in the first half of the 1970s and was interrupted in the early 1980s due to the national crisis in the steel industry. The port then underwent a functional evolution from an industrial port to a multifunctional port. In 1992 the port was completed, at least in maritime works, and in 1993 the Ministry of Transport approved the project, presented by the Contship Group, for the construction of a large container terminal mainly dedicated to transhipment, at the service of unitised traffic and commuter routes between the different continental shores. A transhipment port is a port where large ocean-going container ships (also called "mother ships") transfer containers to smaller vessels ("feeder") for their distribution in a larger number of ports, or to geographical areas where the volume of traffic would not justify the direct call of mother ships.

The evolution from industrial port to third generation port has not been completed and the process is still waiting to be completed. 
The central problem is that an industrial port has two profoundly different characteristics from a third-generation port: it does not need integration with the transport network and it does not need additional capacity beyond that required by the factories it serves. The problem changes radically for a third-generation port which: must have a great integration with the TEN-T transport networks and must have capacity resources to avoid congestion.

The modification of the function of the port took place due to infrastructures built and functional to the industrial port, therefore with limited quays and yards and with little or no integration with the TEN-T networks. To solve these two problems, however, it is necessary to consider another one first: the problem of demand.

Until the whole of the twentieth century it was believed that infrastructure had to be built and then demand would be generated. Today it is now widely recognised that for the definition of an infrastructure and even more for its strengthening, it is first necessary to identify the reference market and then proceed with the evaluation of the works necessary to satisfy the demand.

The issue of completing the transformation remained open due to the lack of a public authority to plan the elements necessary to complete the transformation. In fact, on the one hand the port authority can only operate on the infrastructures inside the port, on the other the management of the railway network has a national responsibility and does not follow the development of the single node. Therefore, the Region can assume an important role, which can plan both internal interventions at the port node and those relating to the network.

Having defined the objective of creating a third-generation port, in Section 2, the methodology used to achieve the objective is presented, proposing a logical and consequential approach that, starting from the question, allows to identify the limits and weaknesses of the node and network infrastructures. The regional plan is then presented which assumes responsibility for decisions, highlighting the role of Gioia Tauro within the Plan itself.

The Gioia Tauro port has never been included in the Regional Transport Plan, even if it is the main transport and economic node of Calabria. The 2016 Plan [2] gives the port a great deal of attention, considering that the port of Gioia Tauro is the first Italian container port and in the last 10 years it has been always in the top five positions of the Mediterranean ports.

The first question regards the current situation of Gioia Tauro port in the international trade, considering the international and the Mediterranean levels (Section 3). The second question concerns the limits and weaknesses that the port has with respect to the role it assumes and that it can develop in international trade traffic (Section 4). Further work analyses the action and the measures that operate to overcome the limits and the weakness exalting the potentiality [3].

\section{THE METHODOLOGY USED IN THE REGIONAL TRANSPORT PLAN}

\subsection{Methodology}

The problem of the transition of Gioia Tauro from an industrial port to a third-generation port [4] was studied using a methodology divided into three main steps. In Fig. 1 the scheme of the developed methodology is presented.

The first step was to rebuild the reference market for the port. The two fundamental functions have been considered: on the one hand the central role as a transhipment node in the context of sea transport, on the other the role - to be developed - of a place for the increase of added value in goods (all or in part) that pass through it. 


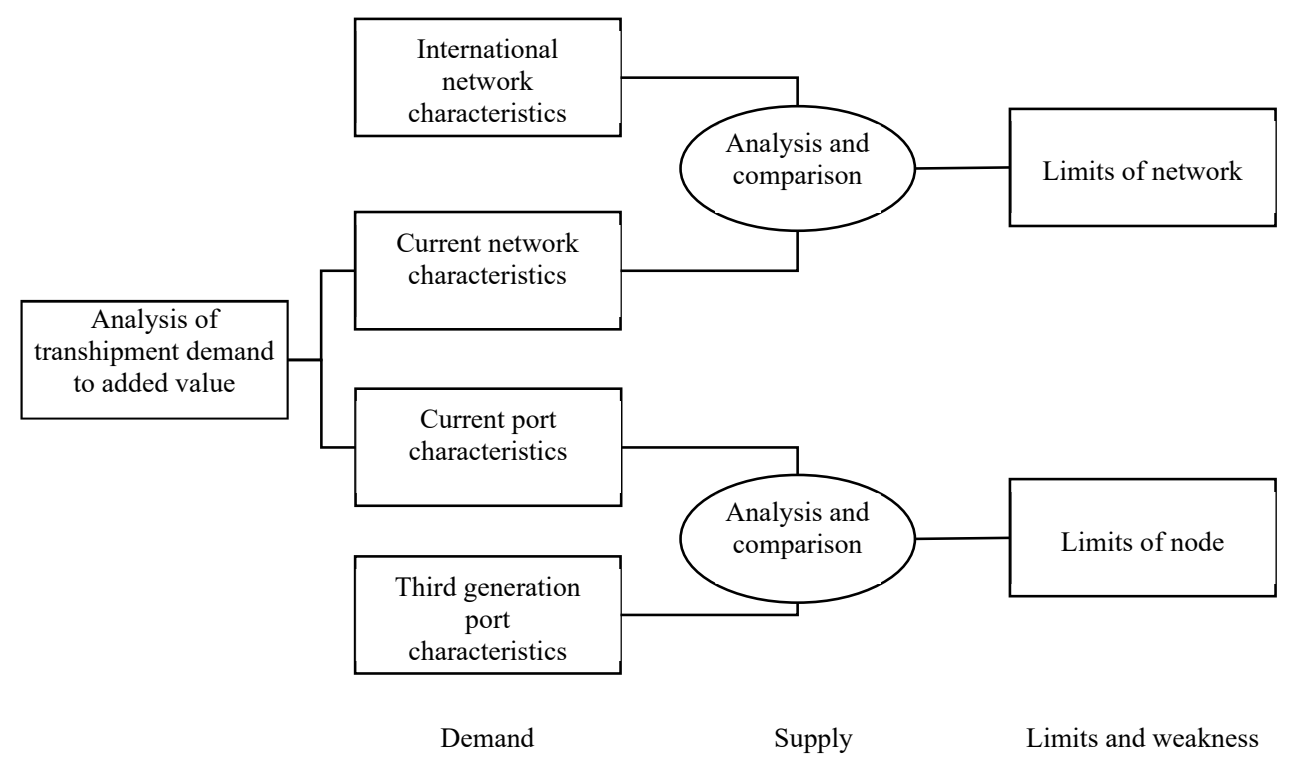

Figure 1: The proposed methodology.

The second step is the analysis of the current infrastructural scenario. The characteristics of the railway network connecting the port to the large European markets are analysed, as well as the infrastructural characteristics of the node, mainly in terms of sea side capacity. The elements of the future scenario for rail freight services as defined in the most advanced literature and the characteristics that the port must have to allow the processing of goods, considering the economic sectors of direct interest to the port itself, are then recalled.

The third step is that of the comparison between the characteristics of the current scenario and the future scenario, from this comparison the current limits and weaknesses emerge in a logical way. The knowledge of the differential between current and future scenario characteristics allows to provide all the actors involved with the indications to proceed in the best possible way in their solution. Deeply different actions, measures and interventions must be developed for design solutions.

The basic analysis and therefore comparison methodology can be extended to ports with similar characteristics, that is, which have started the transformation towards third generation ports but for which the process has not yet been completed. A set of ports that find themselves in this situation is given by the ports of southern Italy for which the Special Economic Zones have been established.

On the basis of the limits found, a specific intervention strategy of the single port is necessary. For the port of Gioia Tauro, the actions and measures to complete the transformation into a third-generation port have been analysed in various works.

\subsection{The plan process}

The Calabria Region carried out a planning process of the transportation system, which a first step resulted in the adoption of the Regional Transport Plan Document (RTP) in December 2016. 
The RTP document was adopted, in its final version, with Regional Government Resolution (RGR) 503 of 06/12/2016; it was approved with Regional Council Resolution (RCR) 157 of 19/12/2016 and positively evaluated by the EU Commission, Directorate General for Regional and Urban Policy as communicated with note 1086324 of 01/03/2017.

The Plan development represents a process of sustainable planning according to several documents delivered at international level starting from 2030 Global Agenda [5]-[9]. The structure of the Plan has been built leaving from a vision defined in four goals: regional economic development, external and internal accessibility, sustainability. From analysis of the current scenario of Calabria, the Plan indicates ten objectives to pursue the four goals, each objective translated into an action and each action is segmented in ten measures, obtaining finally 100 measures.

The Region started programming and implementation of the measures since the approval of the Preliminary Plan Proposal Document. In four years $76 \%$ of the measures have been in programming, and over $90 \%$ of these are in implementation. The bridge from programming to implementation depends on the specificities of the measures, which are heterogeneous and require different timing even for the related administrative procedures.

\section{THE REFERENCE DEMAND OF GIOIA TAURO PORT}

\subsection{Calabria in the international maritime trade}

The role of the PRT and its subsequent implementations, is central to the repositioning of Calabria within the international logistics chains that connect the macro markets of Asia with the EU. Equally important is the role that Calabria can and must have in the exchanges between the EU countries and the countries of the southern shore of the Mediterranean. In this sense, the PRT is fully aligned with the National Strategic Plan for Ports and Logistics (PSNPL) [10], [11] with the choices made on a European scale, with decisions 1315 and 1316 of 2013 [12], [13]. Against a volume of origin-destination container flows by sea of 171 million TEUs worldwide in 2014, the Europe-Asia route and vice versa stood at 20 million TEUs (2013), while the transatlantic route at 6.5 million TEUs. In the Mediterranean basin, the number of containers handled was 60.5 million TEUs in 2013, with an incidence of $8.6 \%$ compared to the world [14]. Some estimates indicate for 2025 a number of containers handled in the Mediterranean between 78 (instability case) and 84 million TEU (recovery case). This rich market segment concerning the Euro-Mediterranean region, mostly served by lo-lo services, is contested between the ports of the European Northern Range and the ports of the Mediterranean. Furthermore, there is competition between the ports "inside" the Mediterranean due to both the birth of new ports and the expansion of existing ones.

Within the Mediterranean, there are significant exchanges of goods between the countries of the northern shore of the Mediterranean with those of the southern shore, operated through ro-ro services. In Italian ports, total ro-ro traffic is estimated at approximately 75.7 million tons/year (2013), with 48.8 million tons/year of cabotage and national traffic, 13.6 million tons/year between the Tyrrhenian ports and the western Mediterranean basin and 13.3 million tons/year from the Adriatic ports to the eastern Mediterranean. A strong potentiality of Gioia Tauro is the development of a high-speed motorway of the sea [15].

The implementation of the RTP would help develop the entire regional economic system, and at the same time national, by proposing an overall reduction in costs and an increase in utility for goods that can be interconnected by the regional node.

The role of infrastructures of national and European interest is decisive in ensuring external accessibility and exchanges between Calabria and the rest of the country and Europe. 
At present, the conditions of national and European infrastructures and services do not guarantee the minimum levels of accessibility for Calabria citizens and businesses.

In the context described above, a fundamental role is played by the port of Gioia Tauro [16], both as regards the logistics system and the role with the regional port system, and for the role played as an economic and transport macro node on a Euro-Mediterranean scale, and for the system of tangible and intangible connections.

\subsection{Sea transport - World}

In the last thirty years, the intercontinental and international maritime transport of goods has had an ever-increasing trend at an historic rate of about $2.2 \%$ per year, with decreases recorded in 1985 and 2009. The total traffic of loaded goods has reached 9.5 billion tons in 2013 [17]-[19].

This growth mainly concerned dry goods and general cargo, a sector within which the weight of the container has grown enormously. Liquid bulk traffic has remained fairly stable over the long term.

With reference to container traffic, in the world the throughput volume, defined as the number of container movements performed by the cranes (ship-to-shore) of a port, went from 441 million TEUs in 2006 to 729 million TEUs in 2014. The average annual growth rate was $10.0 \%$ in the period $1998-2007$, while in the period $2010-2015$ it stood at $8.0 \%$.

The volume of containerised origin-destination flows increased from 127 million TEUs in 2006 to 171 million TEUs in 2014. A mapping of the main routes highlights the growth of the Europe-Asia route and vice versa, which from 2009 to 2011 overtook the route transpacific, to then slowdown in the following years, however growing more than the transatlantic one. In 2013 the Europe-Asia route and vice versa stood at 20 million TEUs, the transpacific route at 21 million TEUs, the transatlantic route at 6.5 million TEUs.

The importance of international maritime transport is related to import - export trade. In Italy, out of all goods traded abroad, about $70 \%$ of imports in quantity (corresponding to $38 \%$ in value) and $50 \%$ of exports (corresponding to $31 \%$ in value) take place by sea [11].

\subsection{Sea transport - Euro Mediterranean}

The throughput volume in Europe went from around 84 million TEUs in 2008 to around 96 million TEUs in 2013 [20]. Breaking down the figure between the Northern Range and the Southern Range, it emerges that the incidence of the Southern Range has gone from 34.9\% in 2008 to $37.9 \%$ in 2013 . However, the competition of the Northern Range ports compared to the Southern Range ports it still remains very strong when it comes to goods entering/leaving Europe (Table 1).

Table 1: Throughput in Europe: decomposition between northern and southern range. (Source: Elaboration from UNCTAD [20].)

\begin{tabular}{lccccccc}
\hline & & 2008 & 2009 & 2010 & 2011 & 2012 & 2013 \\
\hline Southern & MTEUs & 29.3 & 26.7 & 29.0 & 32.0 & 34.6 & 36.5 \\
Northern & MTEUs & 54.51 & 46.64 & 52.73 & 57.12 & 58.84 & 59.76 \\
Total EU & MTEUs & 83.79 & 73.30 & 81.69 & 89.14 & 93.46 & 96.24 \\
Southern & $\%$ & 34.9 & 36.4 & 35.5 & 35.9 & 37.0 & 37.9 \\
Northern & $\%$ & 65.1 & 63.6 & 64.5 & 64.1 & 63.0 & 62.1 \\
Total EU & $\%$ & 100.0 & 100.0 & 100.0 & 100.0 & 100.0 & 100.0 \\
\hline
\end{tabular}


The world trends described above show a growing traffic in the Mediterranean basin. The throughput volume went from 34.0 million TEUs in 2006 to 60.5 million TEUs in 2013. The incidence of throughput in the Mediterranean on world throughput was $7.7 \%$ in 2006, while in 2013 it was attested to $8.6 \%$. By dividing the Mediterranean basin into three areas: North Med (Italy, South France, Spain, Greece) South Med (Morocco, Algeria, Libya, Malta, Tunisia, Egypt) and East Med (Turkey, Lebanon, Jordan, Israel, Syria, Cyprus), the following emerges. In 2006 the North Med countries with their ports absorbed more than $70 \%$ of the throughput, in 2013 this percentage dropped to $57 \%$. The percentage changes in growth are $+206 \%$ in the South Med and $+153 \%$ in the East Med; in the North Med the percentage was $+45 \%$ (Table 2 ).

Table 2: Throughput in the Mediterranean basin: breakdown into three areas. (Source: Elaboration from UNCTAD [20].)

\begin{tabular}{lccccc}
\hline & \multicolumn{2}{c}{2006} & \multicolumn{2}{c}{2013} & Var \% \\
\hline & MTEUs & $\%$ & MTEUs & $\%$ & $2006-2013$ \\
North Med & 24.78 & 72.2 & 36.04 & 57.6 & 45.4 \\
South Med & 4.49 & 13.1 & 13.74 & 22.0 & 206.0 \\
East Med & 5.04 & 14.7 & 12.77 & 20.4 & 153.4 \\
Total & 34.31 & 100.0 & 62.55 & 100.0 & 82.3 \\
\hline
\end{tabular}

Transhipment ports have grown along the main Mediterranean crossing route and are now those with the highest traffic in the area. Competition between ports in the Mediterranean is getting wider both for the increase in the production capacity of new ports and for the expansion of existing ones. However, the strongest competition remains that of ports located in North Africa (Tunisia, Morocco, Algeria, and Egypt), which can offer lower costs linked to three factors:

1. significantly lower labour costs (currently the ratio is 1 to 10 );

2. lower taxation on carriers (anchorage taxes); and

3. lower weight of excise duties on energy and fuels.

Furthermore, the ports of the southern part of the Mediterranean can count on the presence of free zones in the immediate rear-port areas, which allow the establishment of companies at conditions of great tax advantage. It is crucial to underline that the free zone, and more in general the special zone, are the zone suited to the increasing of a decisive value in the freight and then directly involved in the transformation of a port in a third generation.

\section{LIMIT AND WEAKNESS ACTUAL-FUTURE SCENARIOS}

\subsection{The rail network}

The Calabria railway network consists of the national lines of the Ferrovie dello Stato (managed by the company R.F.I., Rete Ferroviaria Italiana) and the regional lines of the Ferrovie della Calabria.

The R.F.I. network is the State Rail Network (SRN). It is developed largely along the regional coastal perimeter; it has a total extension of about $851 \mathrm{~km}$ and has 113 stations with passenger service. In relation to the traction system, the SRN includes $279 \mathrm{~km}$ of electrified double-track lines, $209 \mathrm{~km}$ of electrified single-track lines and $363 \mathrm{~km}$ of non-electrified (diesel-powered) and single-track lines. 
Based on the traffic characteristics, the lines of SRN can be classified in:

- fundamental lines, characterised by a high traffic density and high-quality infrastructure, which constitute the main lines of connection with the national and international network; and

- complementary lines, with lower levels of traffic density, which constitute the link in the region and connect the main lines.

The fundamental lines of the SRN in Calabria are:

- the Tyrrhenian route Praja - Paola - Lamezia Terme - Reggio Calabria, which is the backbone of regional rail transport, with $240 \mathrm{~km}$ of electrified double-track line (but not structured to allow high speed); and

- the Rosarno - S. Ferdinando line (electrified and single track), which connects the port of Gioia Tauro with the SRN, at the Rosarno station.

The Tyrrhenian route, the section of the Ionian line north of Sibari and the transversal lines Paola - Sibari and Lamezia Terme - Catanzaro Lido constitute the Calabrian railway network which is part of the SNIT (Integrated National Transport System) defined in 2001 by the General Plan of Transportation and Logistics [2], [11]. The same lines are also part of the new TEN-T network defined at European scale by Regulation (EU) 1315/2013 of the European Parliament and of the Council of 11 December 2013; in particular, the Tyrrhenian line is included in the core level of the TEN-T network as a conventional railway line and is part of the Scandinavian-Mediterranean European corridor no. 5 (Fig. 2).

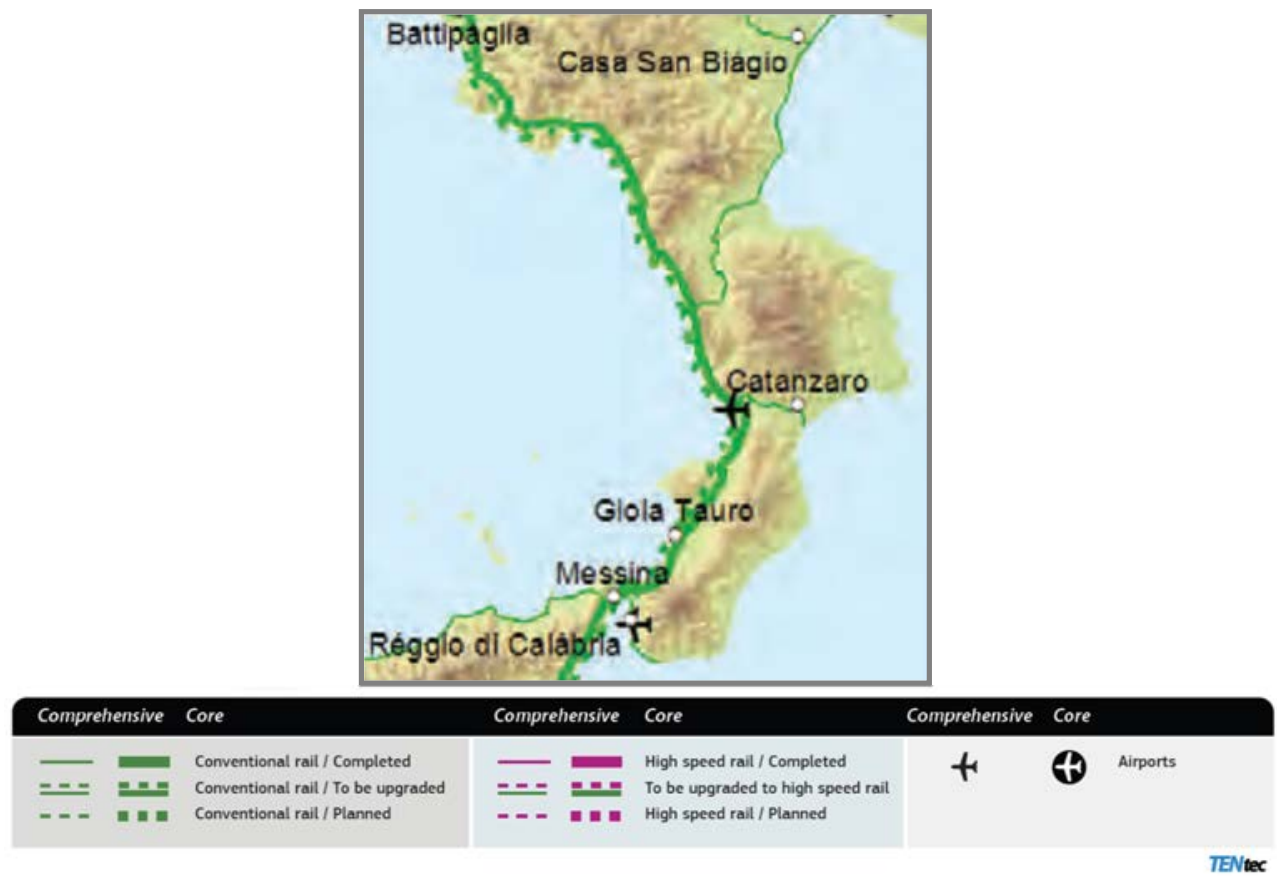

Figure 2: Calabria railway network included in the TEN-T network (Reg. UE 1315, 2013). 
An analysis of the physical and of the performance characteristics of the Calabria SRN network can be operated on the basis of variables, such as:

- the power supply system and the number of tracks;

- the technological system for controlling the movement of trains;

- the limit gauge; and

- the maximum axial load.

With reference to the above variables, the SRN of Calabria related to the Gioia Tauro's port have the infrastructural characteristics summarised below and presented in Figs 3 and 4. To construct the future scenario, reference is made to the EIM report [21] which constitutes the most advanced synthesis for the development hypotheses of European railway networks.
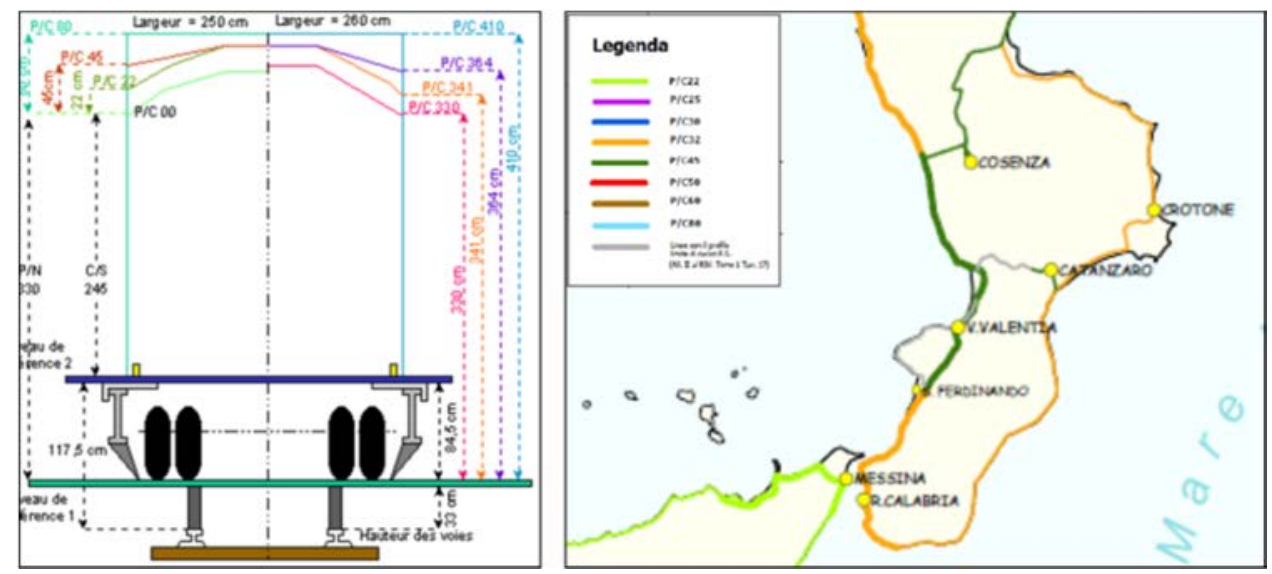

Figure 3: Description of limit shapes and types of shapes in the Calabria Region. (Source: Russo, 2014, http://www.sipotra.it/wp-content/uploads/2014/12/Russo.pdf.)

The EIM report first analyses the demand scenarios and configures supply scenarios on the basis of the demand. The report identifies different segments of freight demand for the future scenario and homogeneous sets of technical characteristics are defined for each. The homogeneous segments are: heavy trains; high speed freight logistic trains, conventional trains. Table 3 shows the main reference characteristics: speed and load per axis. For the train length, the values of the European train $750 \mathrm{~m}$ are reported, noting however that in Germany and France trains of 1,200 and 1,500 m already circulate on conventional lines.

To the capacity of the link between the port and the TEN-T lines it needs to note that from the port of Gioia Tauro, through the Rosarno station, up to 20 weekly block trains were sent in 2008 to the intermodal ports of Nola (Naples), Bari, Frosinone, Padua, Melzo (Milan), Bologna and La Spezia.

\subsection{The port node}

Pursuant to Law 84/94, in the port of Gioia Tauro was established, with D.P.R. of 31 July 1998, the Port Authority of Gioia Tauro, which is a body governed by public law with both administrative and, in part, financial and budgetary autonomy; this body also has functions of direction, planning and control of the activities in port. 


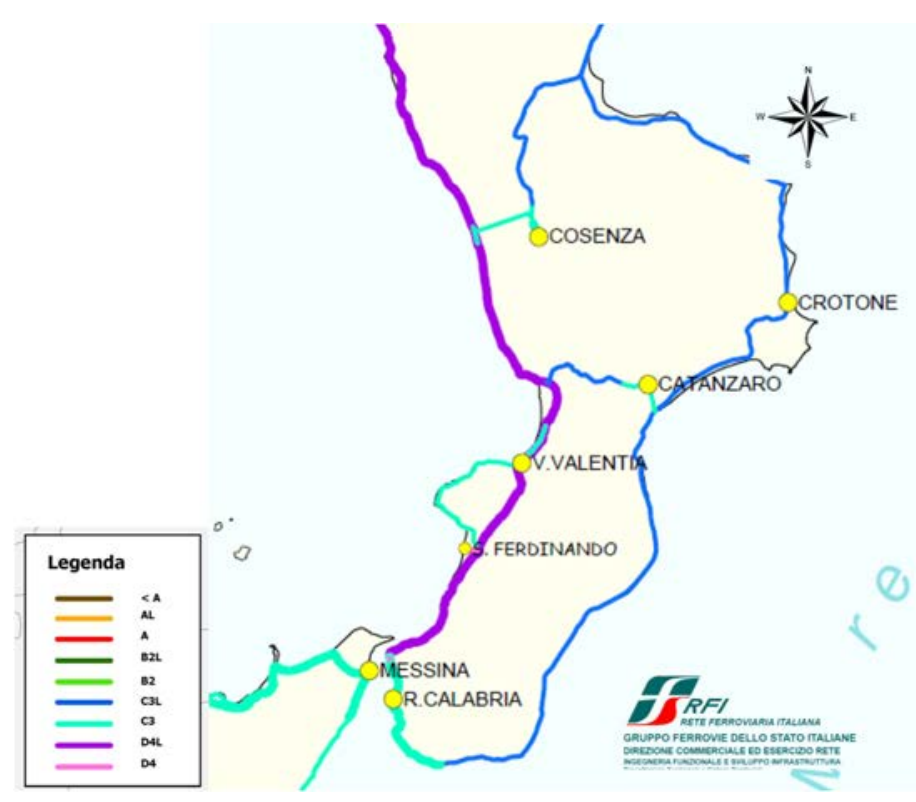

Figure 4: Axial loads admissible on the Calabria railway network. (Source: Italian RFI, 2013.)

Table 3: Main technical characteristics of railway network.

\begin{tabular}{|c|c|c|c|c|}
\hline \multicolumn{2}{|l|}{ Current } & \multicolumn{3}{|c|}{ Future } \\
\hline & & Max speed $(\mathrm{km} / \mathrm{h})$ & 100 & \multirow{3}{*}{ Heavy train } \\
\hline & & Axle load $(\mathrm{t})$ & 35 & \\
\hline & & Train length (mt) & 750 & \\
\hline Max speed $(\mathrm{km} / \mathrm{h})$ & 120 & Max speed $(\mathrm{km} / \mathrm{h})$ & 120 & \multirow{3}{*}{ Conventional train } \\
\hline Axle load (t) & 22 & Axle load (t) & 25 & \\
\hline Train length (mt) & 500 & Train length (mt) & $1,200-1,500$ & \\
\hline \multirow[t]{3}{*}{ (2) } & & Max speed $(\mathrm{km} / \mathrm{h})$ & 250 & \multirow{3}{*}{$\begin{array}{l}\text { High speed freight } \\
\text { logistic trains }\end{array}$} \\
\hline & & Axle load $(\mathrm{t})$ & 18 & \\
\hline & & Train length (mt) & 750 & \\
\hline
\end{tabular}

The port of Gioia Tauro is the only Calabria port that is part of the SNIT (Integrated National Transport System) defined in 2001 by the General Transport and Logistics Plan; it is also the only port in Calabria included in the core level of the TEN-T network defined on a European scale by Regulation (EU) 1315/2013 [12].

As mentioned above, the port was planned in the 1960s as an industrial port and was built starting from the mid-1970s. At the beginning of the 1990s the functional destination was changed, transforming it into a transhipment port.

The port became operational in 1995 and its activity developed at a rapid pace, assigning the port, in a short time, the leading role in the Mediterranean in the transhipment sector. From the 16,034 TEUs handled in 1995, it has gone, after only 3 years, to over 2 million TEUs, up to over 3.4 million TEUs in 2008. From 2008 onwards, the port of Gioia Tauro has shown signs of loss of competitiveness, due both to the opening of new ports that have 
superior logistical advantages, and to a number of other economic and social factors that permits to individuate as third generation ports. Compared to 2010, the transhipment activity of the port of Gioia Tauro recorded a decrease of about $19 \%$ in 2011, essentially due to the abandonment of the port by the Maersk group, the Danish company that alone handled about a quarter of all port volume of container traffic and which has moved its ships to Port Said and Tangier Med.

It must be recalled that: (1) the main operational area of the port is currently constituted by the container terminal in concession to M.C.T. (Medcenter Container Terminal, a Contship Group company) which develops along the east side of the canal, benefiting from approximately $3,400 \mathrm{~m}$ of operational docks and approximately $1,558,000 \mathrm{~m}^{2}$ of yards for the storage and handling of containers and for related processing; (2) the squares adjacent to the northern evolution basin host a car terminal (managed by the company BLG-Automobile Logistics Italia), with an area of approximately $240,660 \mathrm{~m}^{2}$ together with an additional adjacent area of approximately $40,000 \mathrm{~m}^{2}$ with service facilities.

Considering the container moved in the port, it emerges the possibility to organise a logistic base [22]-[25] where the added value of the freight can be increased in the sector: general logistics; agri-food logistics; mechanical and automotive logistics. In this way the limit of the port - to stay only transhipment port - can be transformed in an opportunity to become a third-generation port. The presence of MCT, which is one of the largest international operators of general logistics, and of BLG, which is one of the most important international automotive logistics operators, indicate those of potential significant development in the two sectors. The presence of medium-sized operators with high innovative capacity in the agrifood sector, such as Callipo spa, makes it possible to identify the third sector with great potential in the agri-food sector.

The greatest strength of the port of Gioia Tauro is represented by its barycentric location with respect to the intercontinental routes that cross the Mediterranean basin from one extreme to the other, from Suez to Gibraltar.

Additional strategic elements are:

- $\quad$ suitable infrastructural equipment and good physical characteristics (deep sea beds, straight quays, large storage areas close to the quays, etc.) that allow to accommodate transoceanic ships in transit in the Mediterranean and connect the port through a dense feeder network to more than 50 Mediterranean ports and

- its location on the continental territory, which allows a direct connection with the European terrestrial infrastructure network.

The reference parameters for the comparison of a port are necessarily aggregated and must be specified in terms of actions and measures. As a reference it can be considered the two main functions that a third-generation port must pursue: transport functions and functions for increasing the added value. Table 4 summarises the current and benchmark characteristics.

For the transport functions the sea side components and the land side components must be considered and reference is made to the indications UNCTAD [1] and to the literature indications ([4] and literature cited therein). For the added value functions, the main elements of the three economic sectors involved must be considered and referenced to the main limits of Gioia Tauro, in relation to the infrastructures present in the ports that manage the similar sectors. 
Table 4: Weakness of port node.

\begin{tabular}{|l|l|l|l|}
\hline & & $\begin{array}{l}\text { Current scenario } \\
\text { (RTP 2016) }\end{array}$ & $\begin{array}{l}\text { Future scenario - } \\
\text { III generation port }\end{array}$ \\
\hline \multirow{2}{*}{$\begin{array}{l}\text { Transport } \\
\text { function }\end{array}$} & Square & All busy & Available space resource \\
\cline { 2 - 4 } & Quay & $40 \%$ required 18 mt & Required 18 mt \\
\cline { 2 - 4 } & Railway & No gateway & Gateway \\
\hline \multirow{3}{*}{$\begin{array}{l}\text { Added value } \\
\text { function }\end{array}$} & General logistics & & Cold pole \\
\cline { 2 - 4 } & Agrifood & Isolated companies & $\begin{array}{l}\text { Multi-storey automotive } \\
\text { Shipbuilding } \\
\text { Metal carpentry }\end{array}$ \\
\cline { 2 - 4 } & Automotive mechanical & Isolated companies & \\
\hline
\end{tabular}

From the comparison between current and future scenarios, the limits for the complete evolution of the port towards the third generation emerge. However, it should be noted that the qualifying characteristics of the port are still decisive and the limits can be overcome with adequate actions and measures.

\section{CONCLUSIONS}

In this work, the possibility of a port evolving towards the third generation was examined, despite having been planned and built as an industrial port. A methodology has been proposed which, starting from the analysis of the potential demand and from the infrastructural characteristics of the port and of the connections to the main railway network, allows to identify the limits that prevent this development. The methodology was applied to the port of Gioia Tauro which is one of the most important in the Mediterranean for transhipment.

The results obtained are significant for the port analysed because they allow to identify clusters of interventions that can overcome the identified limits, concentrating the investments only on the works aimed at overcoming the limits.

More generally, the proposed methodology and the possibility of obtaining significant results can be applied in other ports which aim to become a third-generation port, being an industrial port. The problem is particularly important for ports where special economic zones are being created. Various ports are found in these conditions along the coasts of the Mediterranean, starting with the ports of southern Italy. Note that only recently built ports can be born as third generation ports, such as the aforementioned Port Said and Tanger to the east and west of the Mediterranean. Seven special economic zones are under construction in Italy, including one in Gioia Tauro, which aim to transform the reference port into a thirdgeneration port. Some ports in northern Italy, others in the Hellenic peninsula and still others in the Iberian one are planning this evolution, considering only the Mediterranean basin. The work presented here may be useful for planners and researchers working on the topic of third generation ports.

\section{ACKNOWLEDGEMENTS}

The Plan has been developed along the regional administration directed by Mario Oliverio (2014-2020). Many stakeholder and various regional offices participated in the development of the Plan. Some parts of this paper derive from plan document, the present synthesise its effected by the authors. 


\section{REFERENCES}

[1] UNCTAD Secretariat, Port marketing and the challenge of the third generation port. UNCTAD Secretariat, 1992.

[2] Regione Calabria, Piano Regionale dei Trasporti. Regione Calabria, Catanzaro, 2016.

[3] Russo, F. \& Chilà, G., Structural factors for a third-generation port: Actions and measures for Gioia Tauro in the regional transport plan. WIT Transactions on the Built Environment, vol. 204, WIT Press: Southampton and Boston, accepted for publication, ISSN 1743-3509.

[4] Russo, F. \& Musolino, G., Quantitative characteristics for port generations: The Italian case study. International Journal of Transport Development and Integration, 4(2), pp. 103-112, 2020. DOI: 10.2495/TDI-V4-N2-103-112.

[5] Russo, F., Chilà, G., Fortugno, G., Pellicanò D. \& Trecozzi M.R., Transportation planning process in a non-core European region: From sustainability vision to implementation monitoring. International Journal of Sustainable Transportation (Submitted).

[6] European Commission, White paper on transport. Roadmap to a single European transport area - Towards a competitive and resource efficient transport system. 2011. https://ec.europa.eu/transport/sites/transport/files/themes/strategies/doc/2011_white_ paper/white-paper-illustrated-brochure_en.pdf.

[7] European Conference of Ministers of Transport, Safe \& Sustainable Transport, A Matter of Quality Assurance, ECMT, 2003.

[8] United Nations, Transforming Our World: The 2030 Agenda for Sustainable Development, 2015. https://sustainabledevelopment.un.org/content/documents/ $21252030 \% 20$ Agenda $\% 20$ for $\% 20$ Sustainable\%20Development $\% 20$ web.pdf.

[9] United Nations, Global Indicator Framework for the Sustainable Development Goals and Targets of the 2030 Agenda for Sustainable Development, 2018. https://unstats.un.org/sdgs/indicators/Global\%20Indicator\%20Framework\%20after\% 20refinement_Eng.pdf.

[10] Ministero dell'Ambiente e della Tutela del Territorio e del Mare, Strategia Nazionale per lo Sviluppo Sostenibile, 2017. https:/www.minambiente.it/sites/default/files/ archivio_immagini/Galletti/Comunicati/snsvs_ottobre2017.pdf.

[11] Ministero delle Infrastrutture e dei Trasporti, Piano Strategico Nazionale della Portualità e della Logistica, Elaborato dal, Adottato con l'art. 29 comma 1 della Legge 11/11/2014, n. 164, "Conversione in legge, con modificazioni, del decreto-legge 12 settembre 2014, n. 133, recante misure urgenti per l'apertura dei cantieri, la realizzazione delle opere pubbliche, la digitalizzazione del Paese, la semplificazione burocratica, l'emergenza del dissesto idrogeologico e per la ripresa delle attività produttive", (GU n. 262 del 11 novembre 2014, Supplemento Ordinario n. 85).

[12] Regolamento (UE) n. 1315/2013 del Parlamento europeo e del Consiglio, dell'11 dicembre 2013, sugli orientamenti dell'Unione per lo sviluppo della rete transeuropea dei trasporti e che abroga la decisione n. 661/2010/UE. Testo rilevante ai fini del SEE, (GUL 348 del 20 dicembre 2013), pp. 1-128.

[13] Regolamento (UE) n. 1316/2013 del Parlamento europeo e del Consiglio, dell'11 dicembre 2013, che istituisce il meccanismo per collegare l'Europa e che modifica il regolamento (UE) n. 913/2010 e che abroga i regolamenti (CE) n. 680/2007 e (CE) n. 67/2010. Testo rilevante ai fini del SEE. (GU L 348 del 20 dicembre 2013), pp. 129-171. 
[14] Russo, F. \& Musolino, G., Estimating demand variables of maritime container transport: An aggregate procedure for the Mediterranean area. Research in Transportation Economics, 42, pp. 38-49, 2013.

[15] Russo, F. \& Chilà, G., The high speed potentiality in the motorway of the sea: A model choice model. Proceedings of European Transport Conference 2009, Leiden Leeuwenhorst Conference Centre, Netherlands, 2009.

[16] Russo, F., Rindone, C. \& Panuccio, P., Structural factors for a third-generation port: Between hinterland regeneration and smart town in Gioia Tauro. WIT Transactions on the Built Environment, vol. 204, WIT Press: Southampton and Boston, accepted for publication, ISSN 1743-3509.

[17] Ministero Infrastrutture e Trasporti, Area Logistica Integrata Del Polo Di Gioia Tauro Documento Di Sviluppo E Di Proposte. PON Infrastrutture e Reti 2014-2020, Roma, 2018.

[18] Russo, F., Musolino, G. \& Assumma, V., An integrated procedure to estimate demand flows of maritime container transport at international scale. International Journal of Shipping and Transport Logistics, 6(2), 2014.

[19] Russo, F. \& Musolino, G., Geographic factors affecting the presence of transhipment services in regional maritime container markets. Geographical Analysis, 45, pp. 90$102,2013$.

[20] UNCTAD, Review of Maritime Transport, 2014. unctad.org/en/PublicationsLibrary/ rmt2014_en.pdf.

[21] EIM - European Rail Infrastructures Managers, European Railway Technical Strategy, 2008.

[22] Cascetta, E., Nuzzolo, A., Biggiero, L. \& Russo F., Passenger and freight demad models for the Italian transportation system. Proceedings of WCTR 1995, Sydney, 1996.

[23] Musolino, G. \& Chilà, G., Structural factors for a third-generation port: Planning general logistics interventions in Gioia Tauro. WIT Transactions on the Built Environment, vol. 204, WIT Press: Southampton and Boston, accepted for publication, ISSN 1743-3509.

[24] Musolino, G. \& Trecozzi, M.R., Structural factors for a third-generation port: Planning interventions for agri-food logistics in Gioia Tauro. WIT Transactions on the Built Environment, vol. 204, WIT Press: Southampton and Boston, accepted for publication, ISSN 1743-3509.

[25] Musolino, G., Cartisano, A. \& Fortugno, G., Structural factors for a third-generation port: Planning interventions for mechanical logistics in Gioia Tauro. WIT Transactions on the Built Environment, vol. 204, WIT Press: Southampton and Boston, accepted for publication, ISSN 1743-3509. 